\title{
O ACORDO LEGAL JUSTO PROPOSTO NO LIVRO II DA “REPÚBLICA” DE PLATÃO
}

\author{
Diogo Norberto Mesti* \\ diogomesti@yahoo.com.br
}

\begin{abstract}
RESUMO O objetivo deste artigo é investigar a justificativa para o contrato no início da história do pensamento político grego, tendo em vista o

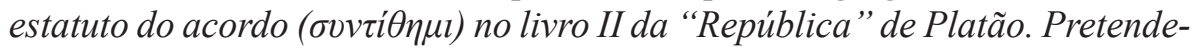
se avaliar como Glaucon apresenta o contratualismo da maioria das pessoas como um desdobramento da tese de Trasímaco de que o justo é o vantajoso para o mais forte e em conexão com os valores que levam as pessoas a admitirem a necessidade do contrato em razão do medo que elas possuem daquilo que poderia ser considerado o maior mal: sofrerem injustiças e não poderem se vingar, enquanto abdicam do que consideram como o maior bem: cometer injustiças sem serem punidas.
\end{abstract}

Palavras-chave Acordo, Justiça, Valores, Glaucon, "República".

ABSTRACT The aim of this paper is to investigate the justification for the contract in the early history of the Greek political thought, focusing on the statute

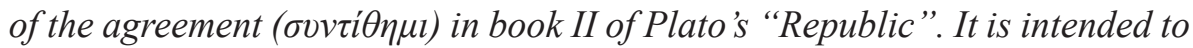
evaluate how Glaucon presents the contractualism of the majority of people in connection with Thrasymachus's thesis that the fair is what's advantageous for the strongest and in connection with the values that lead people to admit the necessity of the contract because of fear that they have about what could be considered as the greatest evil: suffering injustice and being unable to take

* Professor de Filosofia do Direito e Hermenêutica Jurídica no curso de Direito - UEMG (Diamantina). Doutor em Filosofia Antiga (UFMG). Dedico esse artigo ao mais socrático dentre os dialéticos, o mestre imortal Marcelo Marques. Artigo recebido em 10/05/2016 e aprovado em 11/10/2016. 
revenge while they abdicate what they see as the greatest good: doing injustice without being punished.

Keywords Agreement, Justice, Values, Glaucon, "Republic”.

\section{Introdução}

Este artigo não pretende enfrentar os principais problemas envolvendo o estatuto da justiça socrática apresentado na "República" de Platão. A título introdutório, algumas perspectivas sobre a justiça socrática serão retomadas com o intuito de delimitar melhor o lugar do argumento da multidão sobre o acordo legal justo apresentado por Glaucon no livro II da "República". As discussões sobre a concepção socrático-platônica de justiça na "República" (cf. IV 443b-444a) podem ser divididas em duas correntes: ${ }^{1}$ a primeira, que teve mais força na metade do século XX, mas que ainda gera discussões; a segunda, que já gerava discussões na metade do século passado, mas que ganhou força a partir da década de 1980 .

A primeira corrente analisa a definição de justiça apresentada no livro IV da "República" em termos retrospectivos, retomando a discussão presente nos livros I-III. Essa corrente ganhou vigor sobretudo com dois artigos que continuam sendo discutidos ainda hoje ${ }^{2}$ desde a metade do século XX. Tratase do artigo de Sachs (1963) e de Vlastos (1969), onde são discutidas questões como a relação entre a justiça e a injustiça, se há uma coincidência entre justiça psíquica e social, qual é a relação entre justiça platônica e justiça vulgar e se o homem justo é o mais feliz.

A segunda corrente busca analisar a definição de justiça apresentada no livro IV da "República" em termos prospectivos, indo até a discussão sobre o bem nos livros V-VII. Essa corrente já existia na mesma época que a primeira corrente, porém ganhou força somente na década de $1980 .{ }^{3}$ Ela discute o esboço da justiça, a volta maior e como o bem determina a justiça tornando-a útil para a cidade, tendo em vista os símiles do bem como o do Sol e o da caverna. ${ }^{4} \mathrm{~A}$ interpretação da justiça na "República" de Platão depende da posição sobre qual

1 Ambas as correntes estão bem representadas atualmente com os dois volumes editados sobre a "República" por Dixsaut (2005): "Études sur la République de Platon", sendo o primeiro volume Sobre a justiça e o segundo volume sobre A ciência, o Bem e os Mitos.

2 Neschke-Hentschke, 2005.

3 Hitchcock, 1985, pp. 65-92; Santas, 1983, pp. 232-63; Santas, 1985, pp. 223-245.

4 Cairns; Herrmann; Penner, 2007; Anagnostopoulos, 2006, pp. 166-188. 
é o tema central dessa obra. Assim, é preciso responder se a discussão sobre os valores (justiça, virtudes e bem) é um misto de ética e política, uma discussão somente ética ou só política.

\subsection{O lugar do argumento contratualista}

Ao longo desses últimos anos de pesquisas sobre a justiça, pouquíssimos ${ }^{5}$ comentadores investigaram a tese atribuída à maioria das pessoas apresentada por Glaucon. Para a primeira corrente acima referida, tais argumentos descrevem apenas uma justiça vulgar e, para a segunda corrente, o papel do conceito de bem na apresentação que Glaucon faz do contratualismo não mereceu nenhuma atenção. Diante disso, será preciso avaliar a justiça na visão da maioria sem a adjetivação desqualificadora de que ela representa apenas uma justiça "vulgar". Na verdade, essa posição é apresentada a partir de valores e bens que motivam o acordo legal justo, descritos em termos do que a maioria das pessoas considera como o maior bem ou maior mal. Ao fim do presente estudo, tentaremos indicar como a posição apresentada por Glaucon é relevante para a "República" como um todo, retomando Platão para distanciá-lo da tese da maioria apresentada por Glaucon, mas não daquilo que o próprio Glaucon espera de Sócrates no diálogo. Isso será explicado ao fim.

Em geral, a tese do contrato é apresentada simplesmente como algo vulgar e irrelevante para uma discussão a respeito da justiça que seria feita por Sócrates e Platão. O foco deste artigo é corrigir essa postura e investigar as justificativas que a multidão fornece para uma visão contratualista da justiça, além de demonstrar como essa concepção emerge de um cálculo "egoísta" a respeito dos valores (ou bens) a serem perseguidos ou evitados.

Em termos dramáticos, a apresentação da tese contratualista da maioria por Glaucon encontra-se entre a posição de Trasímaco e a de Sócrates. A perspectiva contratualista da justiça se equilibra dramaticamente entre duas teses principais: (i) justiça é a vantagem do mais forte, defendida por Trasímaco; (ii) justiça é o acordo legal, apresentado por Glaucon e (iii) justiça é uma disposição psíquica presente na relação que as partes da alma estabelecem entre si, tese socrático-platônica.

Seguindo os passos de Santas (2006a), pode-se encontrar uma metodologia própria em cada uma das justificações sobre o que é a justiça. O comentador defende que há uma ligação estreita entre a posição de Trasímaco sobre o justo ser o vantajoso para o mais forte com o momento histórico de domínio 
político ateniense. A tese de Trasímaco justifica o imperialismo ateniense, sendo compreendido como histórico ou empírico na medida em que suas conclusões emergem de generalizações "do que é comum nas diferentes sociedades, deduzindo que a justiça é a lei do mais forte" (Santas, 2006a, pp. 126-8). ${ }^{6}$

O debate no livro I termina com Sócrates exaurido por tentar refutar a multiplicidade de concepções de justiça sustentadas pelos poetas e por Trasímaco. O próprio Sócrates admite que agiu como um glutão que acabou ignorando o prato principal, que seria o que é a justiça, ao se esbaldar apressadamente com questões secundárias (I 354b). É diante desse cansaço que Glaucon inicia o livro II apresentando a posição da maioria das pessoas a respeito da "origem e essência da justiça", enquanto Sócrates toma fôlego. Os irmãos Glaucon e Adimanto assumem o diálogo sem deixar Sócrates ir embora e procuram vincular a posição da maioria das pessoas às teses apresentadas por Trasímaco. Glaucon irá esculpir duas estátuas lapidadas em palavras sobre um homem justo e um injusto, afirmando que o justo não se importa em parecer, mas em ser justo, enquanto o injusto se importa em parecer e não em ser justo (II 361c-d). Em termos de capacidade de definir, essa estátua de Glaucon tentar delimitar (331d) a própria justiça.

Mas antes de esculpir suas palavras, Glaucon apresenta o que podemos chamar de contratualismo grego a partir de uma posição que não é assumida como sua, mas advinda da maioria das pessoas. Em geral, as expectativas de que existem aspectos em comum entre os contratualistas modernos e o texto de Platão são sempre confirmadas. No caso de Glaucon, Santas destaca que o contratualismo cumpre com os requisitos do que depois se apresentará tanto em Hobbes, quanto em Rawls, ao indicar "as condições sobre as quais o acordo ou a escolha são feitas - usualmente chamadas de circunstâncias da justiça" (2006a, p. 129). Contudo, há diferenças. A tese apresentada por Glaucon parece radicalizar o pessimismo em relação às motivações que nos levariam para o acordo. O contrato não seria desejado ou gerado por alguma voluntariedade

6 Tucídides faz um retrato disso na "História da Guerra do Peloponeso" (2001, 5. 87-111). O Ateniense diz aos melenses que será melhor eles se submeterem à sua força sem que seja necessário qualquer outro desgaste, mesmo argumentativo. Os melenses são coagidos a nem mesmo tentarem se revoltar contra o domínio dos atenienses poupando suas vidas e o desgaste do exército ateniense, tendo em vista que somente com igual poder se pode desafiar ou resistir a alguém, o que não é o caso dos melenses diante dos atenienses. Pode-se recorrer também à defesa que Cálicles faz do poder do mais forte a partir de evidências retiradas do reino animal e da história política ("Górgias", 483c ss.). Como salienta McNeill, sem entrar na afirmação de uma data definitiva para a "República", é possível sustentar que esse diálogo, bem como o "Górgias", estejam situados num período posterior à morte de Péricles e a rendição dos atenienses para Esparta em 404, que colocou fim à Guerra do Peloponeso (cf. 2010, p. 17). Para mais detalhes sobre Trasímaco, ver McNeill (ibidem, pp. 92-122). É preciso destacar que a própria força aparece também no embate entre Trasímaco e Sócrates, ver: I 341b-c. 
ou busca pelo que é a justiça, já que a maioria só produz o contrato para evitar que todos possam se agredir mutuamente sendo injustos uns com os outros. $\mathrm{O}$ contrato evitaria as injustiças sem necessariamente promover a justiça.

Em outras palavras, não há motivação ou voluntariedade para a justiça presente no contrato. Primeiramente, porque ninguém que pratica a justiça faz isso pensando que ela seria algo bom: "em segundo lugar, todos aqueles que estão perseguindo ela [a justiça] a perseguem involuntariamente ${ }^{7}$ como algo coercitivo, mas não como um bem"s (II 358c). O motivo para os homens fazerem o contrato é evitarem as injustiças advindas dos outros, tendo como causa uma coação externa comum que proíba injustiças. Além disso, não se pode encontrar nesse argumento um momento hipotético anterior ao contrato, no qual os homens não possuiriam consciência em relação à justiça ou aos valores. Há uma concepção de justiça no caso em que todos estão disputando algo e ela consiste na vantagem para o mais forte que poderá ser evitada quando o contrato for feito. A justiça no contrato é obtida pelo sacrifício de um bem em troca do benefício existente em evitar algum mal. Em outras palavras, o contrato é um sacrifício no qual se abdica do maior bem, que é exercer o poder de cometer injustiças contra os mais fracos sem ser punido por isso visando à consequência benéfica de evitar sofrer injustiças. A justiça seria apenas um bem menor e não um bem que é desejado por si mesmo. O motivo e a finalidade da criação do contrato estão vinculados a um tipo de bem que a maioria das pessoas não deseja por ele mesmo, mas somente pelos seus benefícios. ${ }^{9}$

Em comparação com Trasímaco e Glaucon, o método de Sócrates não é tão evidente e se envolve em inúmeras questões que se desdobram antes e terão efeitos depois no desenvolvimento da "República" (Santas, 2006a). Em

7 O conceito involuntário (áćkwv) possui um sentido duplo: por um lado, pode ser compreendido simplesmente como um erro sem motivação específica que tenha se originado na alma humana, por outro, pode ser compreendido como sendo o resultado de uma coação ou da força, na medida em que a motivação para alguma ação seria originada por algo externo ao indivíduo que o obriga a fazer algo como necessário, como se ele estivesse literalmente aprisionado e fosse obrigado a tomar tal atitude mesmo contra a vontade. 0 conceito de involuntário é complementado pelo conceito de restrição ou obrigação, em razão do sentido de prisão ou lugar de restrições: ávaykaĩov (Cf. Liddell, Scott, Jones (Doravante LSJ), ad. Loc.). Essa ideia de uma ausência de uma disposição positiva na alma para fazer a justiça já foi apresentada por Trasímaco quando expõe o argumento de que os homens que censuram a justiça não o fazem visando à própria justiça: "não é por temer praticá-la, mas por temer vir a sofrê-la é que censura a injustiça quem a censura" (Oủ үà

8 As traduções adotadas são em geral de Prado (2006). Em contrário, indicarei, como no caso desta passagem.

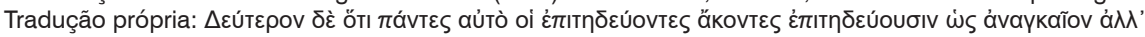
oủx u்s áyäóv.

9 Vejam-se, por exemplo, os argumentos de Allen a respeito dos valores de uma troca comercial, onde ele comenta: "o contrato e as trocas subjacentes a ele na verdade produzem valor, ao menos subjetivamente, em termos de satisfações de desejos. Contrato significa aquilo pelo qual nós, procurando satisfazer nossos desejos, agimos de tal modo a ajudar outras pessoas a satisfazerem os seus" (1987, p. 6). 
geral, pode-se chamar o método de atribuição de funções específicas a cada uma das partes dos membros da cidade e da alma de "funcionalista", em razão da função ("̌pyov) que cada um exerce de modo virtuoso. Assim ocorrerá a definição da justiça no livro: dar a cada um uma função na cidade segunda sua própria natureza (IV $433 \mathrm{a}-\mathrm{c}) .^{10}$

\section{Reciprocidade e o acordo legal}

Um conceito que atravessa as teses apresentadas por Trasímaco e Glaucon é o de reciprocidade. ${ }^{11}$ Em nenhuma dessas teses, a reciprocidade aparece em algum elemento isolado, pois ela exige no mínimo dois elementos que possam estabelecer uma relação de ação e de afecção mútuas, um agindo sobre o outro e sofrendo algo do outro. A troca de ações e afecções recíprocas entre as partes envolvidas poderá ser vista em contratos ou em casos que envolvam justiça ou injustiça entre partes da cidade ou também da alma. A justiça não nascerá das pedras, mas da possível reciprocidade que as pessoas estabelecem entre si mesmas.

Esse conceito foi muito pouco estudado ao longo da história do pensamento político, mas sua proximidade de todas as teses apresentadas na "República" permite compreendê-lo como um elemento comum nesses argumentos. Antes de explicar esse conceito na "República", é preciso salientar que ele emerge do antigo Código de Hamurabi, no qual aparece a lei de Talião do "olho por olho, dente por dente", implicando uma reciprocidade de ação e de punição

10 Para mais detalhes sobre a tese platônica, que não será discutida aqui em detalhes, ver Santas, 2006a, pp. 132-141.

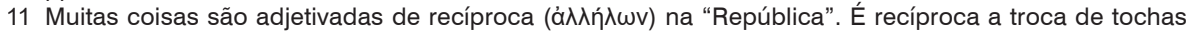
entre pessoas correndo com o cavalo (I 328a); a conversação e sustentação recíproca de Sócrates com seus amigos (I 336c, e); até quando Sócrates fundará cidades para tentar encontrar como se apresenta a justiça, ele busca compreender que a justiça surgirá da relação recíproca entre as pessoas (Cf. 371b; $372 a, 372 b)$. O conceito de reciprocidade também aparece na discussão psicológica que levará a defesa de que a justiça está na relação que as partes da alma estabelecem entre si mesmas (IV 443d). O mesmo conceito de reciprocidade será utilizado quando Glaucon aparece como um interlocutor de Sócrates em um interlúdio do debate de Sócrates com Trasímaco. Isso acontece logo depois da discussão a respeito do governo injusto, em que admitir governantes injustos é considerado como o maior dos castigos para alguém que não quer governar. Mesmo em uma cidade de homens de bens seria difícil encontrar alguém que tivesse a intenção ou disposição para assumir o governo, pois eles lutariam entre si justamente para não assumirem nenhum cargo político. A consequência disso é que eles teriam que aturar o governo de alguém inferior. Nesse momento, Sócrates pretende enumerar argumentos que elogiem a vida dos homens justos para contrapor-se aos argumentos de Trasímaco sobre a felicidade dos homens injustos. Mas para tomar alguma decisão diante desses argumentos seria necessário recorrer a um juiz (סıкaбтńs)

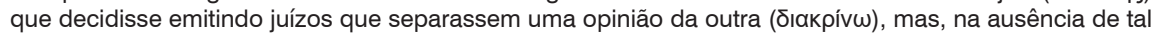
juiz, o exame pode seguir e eles mesmos acabariam "concordando (ávo $\mu$ o內oyoú $\mu \varepsilon v o$ ) reciprocamente

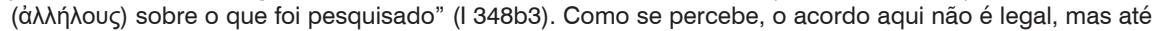
mesmo nos argumentos sobre os acordos legais é importante algum acordo epistemológico sobre a investigação e seus resultados. 
sem qualquer elemento de proporcionalidade. Nesses casos, a punição que o agente injusto receberá será idêntica ao ato que ele cometeu, como ocorre tanto na concepção de justiça pitagórica como reciprocidade, quanto na tese de Radamantis (um dos juízes dos mortos na mitologia grega) em que é necessário sofrer o mesmo que se infligiu. ${ }^{12}$

$\mathrm{Na}$ "República", o conceito de reciprocidade está conectado a diferentes formas de acordos, quase sempre legais. $\mathrm{Na}$ tese de Trasímaco no livro I, a reciprocidade aparece quando ele está defendendo que "os subordinados fazem o que é vantajoso para o mais forte e o tornam feliz, servindo a ele, mas não a si mesmos" (I 343c-d). Para ele, nunca será possível ver os justos ficarem com mais do que os injustos na dissolução de "contratos recíprocos"

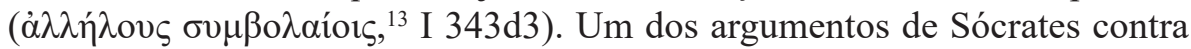
essa tese aparece na defesa de que o resultado imediato da ação de ladrões e

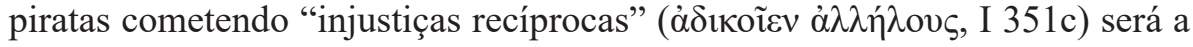
indignação da multidão, de modo que essa injustiça provocaria rebeliões, ódio e lutas "recíprocas" ( $\alpha \lambda \lambda \hat{n} \lambda$ ors, 351d4; d8; 351e1; e3), enquanto somente a justiça proporcionaria concórdia e amizade.

Trasímaco não consegue evitar essas consequências dos argumentos de Sócrates, que aprofundam a tese de que o homem injusto gera efeitos inconvenientes para toda a cidade e para si mesmo, pois seria impossível haver alguma concordância política quando a cidade admite e aceita as injustiças dos mais poderosos. Além disso, o homem injusto não conseguiria agir nem junto de seus amigos e nem em relação a si mesmo, pois estaria em um estado de contínua discórdia. Os injustos seriam incapazes de agir em conjunto uns com os outros ( $\dot{\alpha} \lambda \lambda \hat{\eta} \lambda \omega v, 352 \mathrm{~b} 10)$, pois esses homens não se poupariam reciprocamente e acabariam cometendo injustiças contra eles próprios.

No livro II, o conceito de reciprocidade aparecerá para descrever o que acontece quando os homens cometem e sofrem injustiças reciprocamente ( $\dot{\alpha} \lambda \lambda \eta ́ \lambda$ ovs, II 358e8). E aqui começa a inversão do argumento de Trasímaco, pois o objetivo é tentar encontrar algum instrumento para fazer com que os homens aceitem como necessários os contratos mútuos em que não se possa cometer injustiças livremente. Ainda que o objetivo seja propor algo contra Trasímaco, há certas aproximações entre a tese do contrato e a do mais forte.

12 Para mais detalhes, ver as palavras de Aristóteles: "Ética a Nicômacos": V, 5-6, 113b21-1134a24.

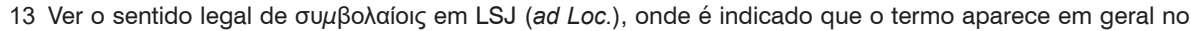

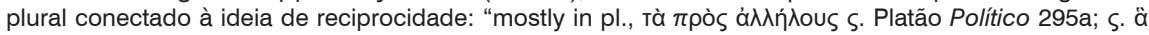

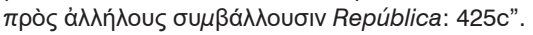


Por um lado, há elementos em comum entre Trasímaco e o que Glaucon irá apresentar. Primeiro, ao explicar o pensamento da maioria, Glaucon defende a disseminação da crença de que o homem injusto é mais beneficiado do que o justo, como Trasímaco defende; em segundo lugar, o fundamento comum entre a tese da maioria e a de Trasímaco é que ninguém censura a injustiça por vontade (ou voluntariedade) de ser justo, mas por medo de sofrer injustiças. Assim, quando Glaucon apresenta o elogio ao homem injusto (II 358d) ao explicar a origem e a essência da justiça para a multidão ele retoma o argumento de Trasímaco sobre aqueles que censuram a injustiça. A afirmação de Trasímaco de que "não é por temer ( que censura a injustiça quem a censura"14 (I 344c, grifo nosso) está presente também naquilo que a maioria pretende evitar pois seria péssimo para os homens (ou seu maior medo): sofrer injustiça sem poder se vingar. Por outro lado, há elementos distintos entre Trasímaco e o pensamento da maioria em relação às injustiças sofridas. Ao contrário da tese de que os justos sempre acabam com menos diante dos injustos no caso da dissolução de contratos recíprocos, Glaucon irá propor que os contratos serão guiados pelo desejo de que o livre cometimento de injustiças seja barrado. Ou seja, mesmo diante da falta de motivação para cometer justiças nas teses da maioria e de Trasímaco, a finalidade para os contratos será distinta.

Para Trasímaco, ser justo e praticar a justiça não trariam nenhum benefício, pois a justiça é um bem alheio para aquele que é governado e não tem força. O bem alheio dos súditos é tratado por ele como algo que é vantajoso para o próprio governante, tanto que nos contratos, nos negócios da cidade e nas funções políticas, quem sempre perderá é o justo, enquanto o injusto que trata o bem como proveito pessoal ganhará. Porém, quase não existem relações interpessoais entre os poderosos ou entre pessoas que cometem injustiças, porque as injustiças seriam cometidas não só contra os governados.

A finalidade do contrato para a maioria das pessoas emerge como uma tentativa de evitar que a maioria sofra injustiças, barrando qualquer privilégio dado ao mais forte que quase não sofre injustiças porque teria o poder de perpetuá-las. Com o contrato, os mais fracos vislumbram evitar que os mais fortes cometam injustiças, ${ }^{15}$ não porque acreditam na eficácia do contrato em

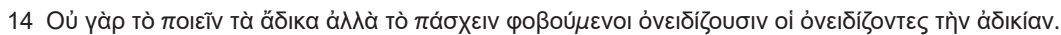

15 No "Górgias", Cálicles sustentará que as leis são feitas pelos mais fracos: "Estou certo de que são os fracos, a maioria das pessoas, que estabelecem as leis. É, portanto, em função deles mesmos e de seus interesses pessoais que os fracos fazem as leis, que eles atribuem honras, que eles distribuem reprimendas. Eles pretendem criar medo entre os homens mais fortes que eles e que poderiam ser superiores a eles. É para impedir que esses homens Ihes sejam superiores que eles dizem que é vil, que é injusto, ter mais do que 


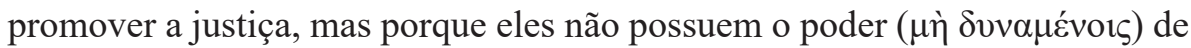
fazer ou de evitar injustiças sozinhos (358e). Essa é a crítica de Trasímaco: quem tem o poder de fazer injustiças não entraria em acordo com os mais fracos. Nesse sentido, o resultado é que, na perspectiva de Glaucon: "a Justiça beneficia o fraco, que se une para obrigar o mais forte a obedecer às suas leis" (Nichols, 1984, p. 33).

A reciprocidade que os homens vão defender como sendo a mais útil no contrato é aquela que os impediria de cometerem e de sofrerem injustiças: "parece-lhes útil estabelecer um contrato que os proíba de reciprocamente cometerem e sofrerem injustiças"16 (II 359a, grifo nosso). O contrato pretende evitar a ausência de punição para aqueles que cometem injustiças, sendo esta ausência de punição o maior benefício concedido aos mais fortes, enquanto indica também que ninguém abdicaria do poder de fazer injustiças de modo espontâneo. No caso de alguém se recusar a cometer injustiças, ele até seria elogiado diante dos outros em público, mas esse elogio seria contraditório porque os homens estariam "enganando-se mutuamente ( $\dot{\alpha} \lambda \lambda \dot{\eta} \lambda \mathrm{ov} \varsigma)$ por medo de sofrerem injustiças"17 (II 360d). A tese de que a justiça não é perseguida como um bem significa que a justiça não seria uma disposição originária da alma humana, mas nasceria de um sentimento negativo de medo em relação ao oposto da justiça: o temor de sofrer injustiça. Os homens temem a injustiça (o medo é o motivo) e só evitam fazer injustiças quando são obrigados a respeitar alguém com igual poder ou constrangidos por um contrato que limite seus poderes (essa é a finalidade da lei). Nada, nem mesmo a lei, é motivo para fazer justiça, mas serve apenas para evitar as injustiças sofridas ou exercidas contra si mesmo ou contra os outros. A justiça no contratualismo grego parece ser estabelecida no contrato com um conteúdo negativo: não fazer injustiças recíprocas.

A tese apresentada por Glaucon de que "a origem e a essência da justiça"

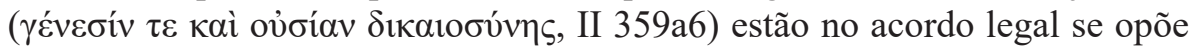
ao que ele mesmo e Adimanto esperam de Sócrates: a defesa de que a justiça é uma disposição da própria alma. ${ }^{18} \mathrm{~A}$ ideia de um "acordo legal" não ocorre

os outros e que a injustiça consiste justamente em querer ter mais. Pois, o que agrada aos fracos é ter o ar de ser igual a tais homens, enquanto eles são inferiores" (483b-c). Para uma leitura sobre Cálicles e o embate com Sócrates, ver Araújo, 2008.

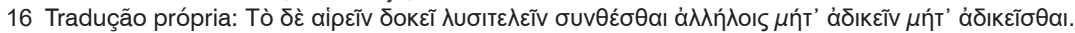

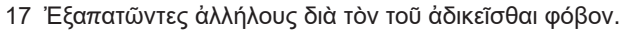

18 Essa oposição entre a justiça como uma disposição psíquica ou como a obediência à lei também está presente na discussão que Aristóteles faz da justiça no início do cap. V da "Ética a Nicômacos". Deve-se destacar que Aristóteles apresenta dois tipos de disposições psíquicas, uma em que a alma está agindo em relação a si mesma e a outra (considerada como excelência moral) em que essa disposição se dirige aos outros. Além dessas duas disposições ele também concebe o justo como obediência à lei. Explicando isso em Platão, Sekimura destaca que Glaucon e Adimanto defendem que a alma não teria um poder interno 
assim conectado no grego, mas pode substituir a seguinte frase: "E foi a partir de então que começaram a compor ${ }^{19}$ tanto suas leis quanto seus acordos e a chamar de legal e justo o comando legal" ${ }^{20}$ (II 359a). Essa passagem apresenta uma

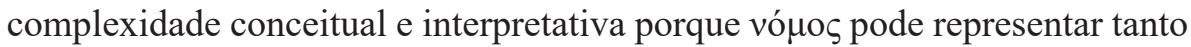
costume, quanto lei e $\sigma v v \theta \eta \dot{\kappa} \eta$ pode significar tanto acordo, quanto convenção. Em certa medida, é como se os homens passassem a reunir seus costumes em um conjunto que se transformaria em uma totalidade que pudesse ser adjetivada

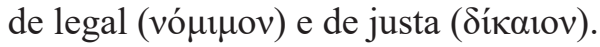

Ainda que o texto não se utilize de $\tau \grave{\alpha} v$ vó $\mu \mu \alpha,{ }^{21}$ que seria mais apropriadamente os costumes, ele parece imprimir uma certa alteração no sentido de costume/ norma (vó $\left.\mathrm{o}_{\varsigma}\right)$ substantivado na primeira parte da frase para o sentido adjetivado de legal (vó $\mu \mu \mathrm{s})$ na segunda parte. Isso só ocorre pela mediação de uma ação de conjugação que está presente no verbo colocar junto ( $\sigma v v \tau i ́ \theta \eta \mu 1)$, ligado tanto ao ato de sintetizar na matemática e combinar na lógica, quanto ao ato de reunir construtivamente algo tendo em vista a composição de um todo, deixando as coisas em acordo ( $\sigma v v \theta \eta ́ \kappa \eta ~ C f$. LSJ, ad Loc.). Assim, dos costumes tradicionais gera-se um acordo que passa a ser considerado como um acordo legal e justo.

\section{A questão dos valores: os bens e o acordo}

Diferentemente de Rawls (2002), que no século XX defendeu uma espécie de contratualismo sem uma base axiológica ${ }^{22}$ evitando o conceito de bem, $\mathrm{o}$ bem está na base do raciocínio da teoria contratualista apresentada por Glaucon, que explica os fundamentos para o contrato por meio de uma quantificação dos

para ser justa, já que "apresentam a justiça ou a injustiça como um poder (סúva $\mu$ ı) que se origina de aparências ilusórias” (2009, p. 230). Isso ocorre porque os homens são guiados pela força da aparência, quando eles se preocupam mais em parecerem justos, do que efetivamente agirem de modo justo, ou também pela força da coerção da lei, quando só fazem justiça porque são obrigados (II 365a-367e). Os irmãos, destaca Sekimura, ficam na expectativa de que Sócrates apresentará "um outro poder retratador que se oponha ao logos da opinião vulgar", defendendo que é preciso investigar tanto o efeito da justiça e da injustiça "como uma capacidade própria (тñ aúToũ ठuvá $\mu \varepsilon ı)$, quando elas estão na alma daquele que a possui e quando elas permanecem desapercebidas aos deuses e aos homens (II366e)" (2009, p. 230).

19 Cf. LSJ, ad. Loc.

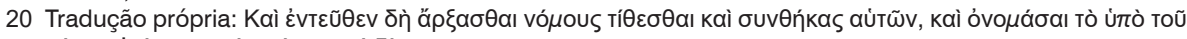

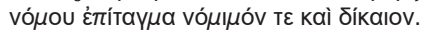

21 Cf. Chantraine, 1968, p. 743.

22 Rawls afirma em seu livro "Justiça como equidade" que nenhuma noção de bem, incluída entre os argumentos que justificam o contrato, poderia ser utilizada porque fragmentaria o ego individual. Ele parece negar que qualquer consideração de um bem maior possa estar nos fundamentos de sua teoria contratualista, defendendo apenas a existência de bens individuais, sobre os quais não se pode elaborar nenhuma teoria. Em contraste com esse bem maior, ele pensa em uma teoria restrita de bens primários que tornam incontornável a defesa da justiça como uma prioridade. Assim, a justiça não seria uma consequência do contrato, mas sua motivação (Rawls, 2002). Para uma relação entre Rawls e Glaucon, ver Santas (2006a, 2010). 
seguintes valores: maior bem, menor bem, maior mal e menor mal. ${ }^{23}$ Isso é o que poderia ser compreendido como a "nova classificação dos bens" que faz frente às teses de Trasímaco (Santas, 2010, p. 32). Ainda que não apareçam de modo explícito esses quatro elementos na sua teoria, é possível descrever a posição apresentada por Glaucon em termos de menores bens e males por uma oposição em relação ao que o texto apresenta sobre os maiores bens e males. ${ }^{24}$ Como já foi apresentado, as motivações psíquicas que levam o homem ao contrato não podem ser consideradas como positivas, pois o raciocínio que o homem faz leva em conta apenas os malefícios e benefícios da injustiça. Isso se origina de um conflito em relação ao prazer de fazer injustiça e o medo de sofrê-la e não exatamente de alguma motivação para fazer alguma justiça. Glaucon defende que os homens estabelecem como seus principais valores um desejo e um medo: o desejo de serem injustos e o medo de sofrerem injustiças. Primeiramente, atribui-se aos homens um desejo natural pelos atos injustos, vistos como se fossem o maior bem: cometer injustiças sem ser punido e, em segundo lugar, atribui-se aos homens um medo de sofrer atos injustos como se sofrê-los fosse o maior mal: sofrer injustiças sem poder se vingar.

Nesse sentido, o contratualismo apresentado por Glaucon só surge porque o mal em sofrer injustiças excede e é maior que os bens proporcionados por cometê-la, sendo esta a principal razão e a única motivação que leva os homens a defenderem o contrato (II 358e): sofrer injustiças sem se vingar é um mal maior. Em outros termos, o contrato não é feito com base nas ações justas e nem no recebimento de justiça, mas para impedir as pessoas de sofrerem injustiças já que em geral pretende-se evitar sempre aquilo que se considera como o maior de todos os males.

23 Pode-se esperar o mesmo papel dos valores na discussão entre Cálicles e Sócrates no "Górgias", onde a discussão passa justamente pela seguinte incitação: Cálicles deveria defender que a seguinte tese estava errada: que cometer injustiças sem poder se vingar não é o pior de todos os males (482b). Todo o embate entre ambos girará em torno dessa tese que Sócrates fez Polo aceitar a contragosto. Para mais detalhes sobre a relação entre a tese apresentada por Glaucon e a pleonexía no diálogo "Górgias", ver Allen, 1987. Para uma visão detalhada do embate entre Cálicles e Sócrates, ver Araújo, 2008.

24 Essa proposta de leitura axiológica do argumento de Glaucon pretende se opor a alguns autores que, apesar de mencionarem Glaucon nos títulos de seus respectivos artigos, apenas fazem referências aos problemas que Glaucon coloca para Sócrates no início do livro II, sem que seja abordado em detalhes o que realmente está sendo apresentado como a opinião da maioria por Glaucon. A história desse debate começa pelo suposto erro de Platão ao dividir os bens em três: (i) aquilo buscado por si mesmo, (ii) por si mesmo e por suas consequências e (iii) só por suas consequências e, no fundo, contribui muito pouco para discutir as teses apresentadas por Glaucon, porque estão interessados em defender se Platão é ou não um eudaimonista (Ver: Foster, 1938; Kirwan, 1965; Gilboa, 1996). Ao não se dedicarem a compreender efetivamente as teses do contratualismo de Glaucon, parte das suas discussões sobre a perspectiva socrática ficou prejudicada. Além destes, deve-se mencionar como um dos raros artigos que cita Glaucon em seu título um que está ligado à corrente analítica de análise de proposições sobre moralidade. Para essa vertente, ver: Tenenbaum, 2000. 
É nesse sentido que Glaucon apresentará a origem do contrato:

Essa é a origem e a essência da justiça que está misturada entre, por um lado, o ótimo: cometer injustiça e não ser punido, e, por outro lado, o péssimo: ser vítima de injustiça e não poder se vingar. A justiça, estando entre esses dois extremos, é amada não como um bem, mas como algo que é honrado por falta de ânimo para cometer injustiça, pois quem pudesse fazer isso e fosse verdadeiramente homem, nem mesmo com uma única pessoa estabeleceria uma convenção que o proibisse de cometer injustiça e de sofrê-la. Isso seria uma loucura de sua parte! Então, Sócrates, eis a natureza da justiça e a sua origem, segundo o que dizem (II 359a-b). ${ }^{25}$

Para Santas, o contrato implica um jogo zero a zero (zero-sum-game), onde ninguém obteria algo a mais do que o outro. Essa soma zero só é rompida se alguém estiver disposto a se tornar injusto para obter aquilo que considera individualmente bom. Não há referência à "inteligência" desses homens ou à sua racionalidade, mas a uma capacidade calculativa e "minimamente racional" que permite que eles pensem e coloquem na balança seus objetivos próprios e quais bens comuns eles procuram. Trata-se de um cálculo de paixões, sentimentos e ações, onde eles terão que ponderar entre o que estão dispostos a evitar (sofrer injustiças) e quais ações eles estão dispostos a não cometer (serem injustos). E isso é revelador porque mostra que eles admitem somente que "o ruim de ser injuriado supera o bem obtido por injuriar os outros" (2006a, p. 130).

A tese exposta por Glaucon para explicar a origem da justiça é que os homens criaram um contrato mútuo que se equilibra entre o maior mal: sofrer injustiça sem poderem se vingar e o maior bem: cometer injustiça sem serem punidos, de modo que a justiça é amada no máximo como um bem menor em relação ao bem maior que seria ser injusto. Como foi dito, o contratualismo ainda admite um elogio ao injusto defendido por Trasímaco, quando afirma que ser injusto é o maior bem. Nesse sentido, a injustiça é censurada pelo medo de sofrê-la e não pelo medo de praticá-la. Só seríamos levados à justiça pela obrigação de abandonarmos o maior bem pelo menor bem, restringindo nossas ações injustas. Em outros termos, é possível compreender que o menor bem, que não aparece no texto, poderia ser compreendido como ter uma atitude justa em relação aos outros evitando fazer injustiças contra eles.

Em determinado momento, Adimanto complementa a fala de Glaucon, indicando uma inversão desses valores que eles encontram no pensamento da

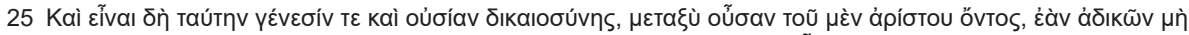

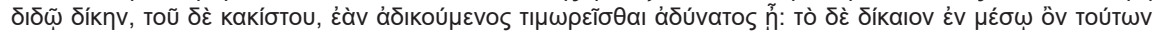

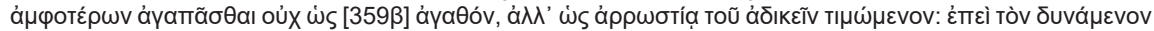

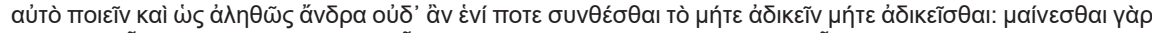

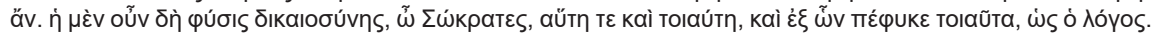


maioria das pessoas. Esses valores "invertidos" são os que eles esperam que Sócrates defenda:

Quanto ao que a justiça e a injustiça são por elas mesmas, em razão de uma força que há dentro da alma de quem as possui, isso passa despercebido aos deuses e aos homens e ninguém jamais demonstrou a contento, em poesia ou prosa, que uma é o maior dos males que a alma tem dentro de si e a outra, a justiça, é o maior dos bens. Se isso fosse dito desde o início por todos vós e se disso nos persuadísseis desde nossa juventude, não nos vigiaríamos reciprocamente ( $\dot{\alpha} \lambda \lambda \hat{n} \lambda \mathrm{ov \zeta})$ para que não cometêssemos injustiças, mas, ao contrário, cada um seria seu próprio vigia, temendo que, por cometer injustiça, tivesse de conviver com o maior dos males (II 366e-367a). ${ }^{26}$

A questão é que para a maioria das pessoas o maior bem é cometer injustiça e o maior mal sofrê-la. Glaucon e Adimanto esperam que Sócrates inverta essa tese e defenda a injustiça como o maior mal e a justiça como o maior bem que a alma pode ter dentro de si. Isso serviria para se opor àquilo que a maioria das pessoas naturalmente acredita, que cometer injustiças é o maior bem e sofrê-la o maior mal.

\begin{tabular}{|c|c|c|}
\hline & Maioria das pessoas & Sócrates \\
\hline Maior Bem & Cometer injustiça & Fazer a justiça \\
\hline Menor Bem & Não cometer injustiça & Receber justiça \\
\hline Maior Mal & Sofrer injustiça & Cometer injustiça \\
\hline Menor Mal & Não sofrer injustiças & Sofrer injustiça \\
\hline
\end{tabular}

Aparecem aqui duas alternativas opostas em relação ao que pode ser considerado como o maior bem e o maior mal. Glaucon e Adimanto esperam que Sócrates apresente como maior bem possuir a justiça dentro de si e como maior mal a injustiça, para inverter as teses de Trasímaco e também da maioria das pessoas que acabam elogiando o injusto. A tese da maioria sobre como os homens chegam ao contrato apresenta um cálculo egoísta e pessimista acerca dos valores mais importantes a serem seguidos (maior bem: ser injusto sem ser punido / $\mu \varepsilon ́ \gamma 1 \sigma \tau o v \dot{\alpha} \gamma \alpha \theta$ óv), quais valores eles estariam dispostos a adotar caso

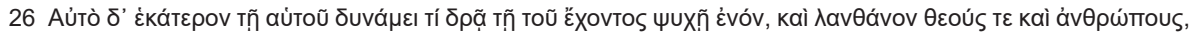

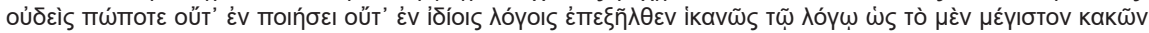

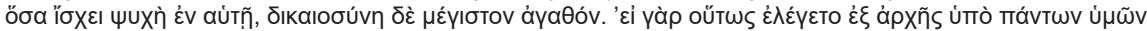

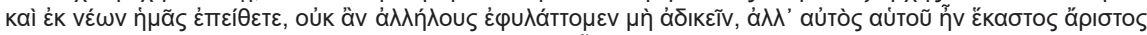

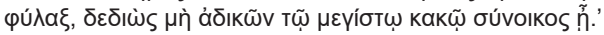


esse valor maior não possa ser atingido (menor bem: não cometer injustiças ou ser justo com os outros) e quais valores eles temem mais (maior mal: sofrer injustiça sem se vingar / $\mu \varepsilon ́ \gamma 1 \sigma \tau o v \kappa \alpha \kappa \tilde{v}$ ), bem como qual valor eles temem menos e estariam dispostos a aceitar (menor mal: não sofrer injustiças).

\subsection{Anel de Giges: entre o egoísmo e a coerção}

A história do Anel de Giges ${ }^{27}$ baseia-se nos mesmos valores que fundamentam o acordo legal e chega a expandir o caráter pessimista da natureza humana já exposto. Essa expansão ocorre porque até mesmo o homem justo cometeria os maiores males se ele percebesse que não seria punido em razão da invisibilidade do anel. Inclusive ele não resistiria àquilo que é o maior bem para a maioria: ser injusto sem ser punido.

A invisibilidade torna-se um meio de maximização da ambição individual, criando um mundo de inimputáveis em que atos injustos não seriam punidos e as pessoas não seriam responsabilizadas. $\mathrm{O}$ justo buscaria a mesma ambição

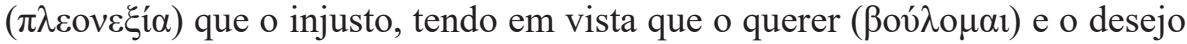
( $\dot{\pi} \imath \theta v \mu i ́ \alpha)$ natural de todos os homens é obter sempre mais vantagens (II 359c). ${ }^{28}$ Esse movimento psíquico conecta-se à natureza humana, pois a ambição é "aquilo para o que toda natureza se dirige como se fosse um bem" (tradução própria: ô

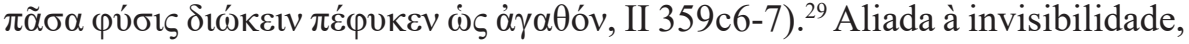
a pleonexía faz com que os homens desejem como um bem obter mais do que aquilo que já possuem, tornando-se cada vez mais injustos porque ninguém será punido por seus excessos.

A sequência da história apresenta a necessidade de que exista alguma força que obrigue o homem a respeitar e valorizar a igualdade: pois "a lei com força

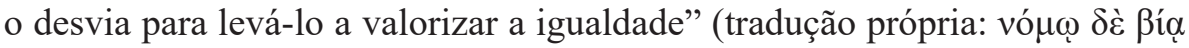

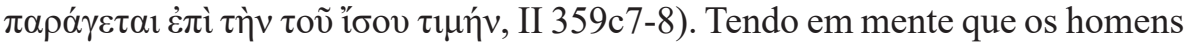
não buscam a justiça naturalmente e que raramente aparece no texto uma ação justa voluntária, o contrato impõe uma força ou coerção que os obriguem a não cometerem injustiças. Além de força física ( $\beta i ́ \alpha)$, aparece também o conceito de

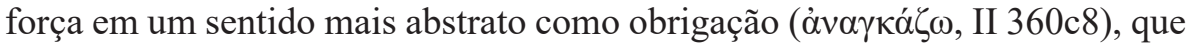

27 Para um estudo sobre como Glaucon reescreve a história de Giges que primeiramente apareceu em Heródoto, ver Nichols, 1984, p. 33 ss..

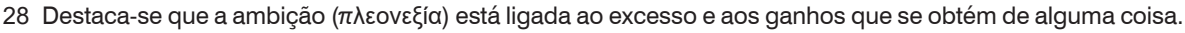
LSJ, ad Loc.

$29 \Delta$ เ algo, como querer e desejar. A frase em questão promove o entrelaçamento de dois verbos ligados aos

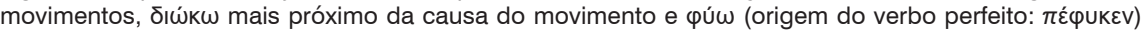
ligado ao efeito que é gerado, na medida em que possui o sentido de algo sendo engendrado e criado. Cf. LSJ, ad Loc. 
possui também no texto o sentido de restrição ou aprisionamento (II 358c) e é utilizado para limitar as pessoas em suas ações injustas. O contrato deve impor uma obrigatoriedade universal que seja capaz de coagir e punir aqueles que infringirem a regra de não ser injusto. $\mathrm{O}$ contrato deve aprisionar o desejo e a ambição por atos injustos, instituindo que a lei se aplique a todos de modo igual. É com o conceito de igualdade que o contratualismo da maioria se diferenciará da função e da finalidade da lei defendidas por Trasímaco. ${ }^{30}$

Quando o contrato impede as pessoas de cometerem injustiças umas contra as outras é inaugurada, quase de modo rarefeito, uma espécie de valorização

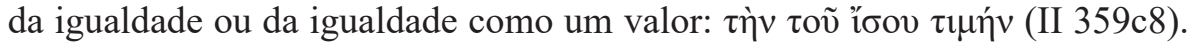
Com o contrato, as forças dos indivíduos serão igualmente submetidas à força do contrato que impedirá os homens de serem injustos uns com os outros. A igualdade emerge como limitação do poder individual de cometer injustiças, tentando promover uma igualdade entre os mais fracos e os mais fortes que não será completamente aceita pelos mais fortes. Em outras palavras, na visão contratualista da maioria apresentada por Glaucon, “o homem justo é simplesmente um homem que suportaria a igualdade em razão da ausência de um poder para obter mais do que ele recebeu pelo que foi repartido" (Allen, 1987, p. 4), enquanto o homem injusto e mais forte diria apenas que esse contrato visa à vantagem dos mais fracos.

Mais uma vez, trata-se de uma tese oposta à tese de que o homem possui uma motivação psíquica para ser justo, como irá defender Platão. Aliás, na história do anel é considerado fraco alguém que encontra alguma motivação interna para se abster de cometer atos injustos e evitar tocar na posse alheia, sobretudo enquanto possui o poder da invisibilidade. ${ }^{31}$

A história do Anel de Giges é construída a partir da conclusão a respeito dos valores das pessoas que farão o contrato: cometer injustiças sem ser punido e da ideia de que todos poderiam fazer aquilo que bem entendem. Diante disso, não é em razão da ausência de estado ou do contrato que o homem seria injusto e não há uma transição temporal entre um antes: um momento pré-contratual injusto e uma motivação pelo contrato justo, bem como não há um cálculo ou

30 Allen explica muito bem essa distinção quando afirma que: "com a intenção de obter o que é nosso, devemos ajudar os outros. Contrato implica a possibilidade de uma interdependência genuína, não um atomismo radical. [...] Se o contrato for uma metáfora para a sociedade, em relação às trocas, nós estamos constantemente firmando nos contratos de relações ordinárias não apenas o negócio explícito, mas elementos muito mais profundos sobre trocas e reciprocidades envolvidas no fato de que pertencemos à mesma ordem social, que cada um de nós precisa para nossa existência" (1987, p. 8).

31 Para mais detalhes sobre esse personagem estranho que faria a justiça mesmo diante da hipótese de que ele não seria punido porque estaria em posse do anel que tem o poder de deixá-lo invisível, ver Brown, 2007 , p. 49 ss. 
uma motivação por mais justiça que leva os homens ao contrato. ${ }^{32}$ Isso é provado com o desdobramento da história do Anel de Giges, onde até mesmo o justo se tornaria injusto. E isso evidencia a necessidade e o poder coercitivo da lei para coibir o homem a cometer injustiças livremente. Esse argumento reforça a tese do pessimismo em relação à natureza humana e da impossibilidade de a injustiça surgir por alguma motivação individual.

Entre os argumentos da maioria e de Trasímaco existe também um deslocamento do conceito de força. No pensamento contratualista a força estará no contrato, que punirá aqueles que se utilizarem da força individual para cometerem injustiças e não se sentirem coagidos a deixarem de cometer injustiças uns contra os outros. Por um lado, se a injustiça for incentivada e perpetuada pelos contratos, estaríamos presos a um conceito de reciprocidade punitiva e perversa que está na origem das teses que ainda hoje pretendem fazer justiças com as próprias mãos. Por outro lado, somente com a injustiça sendo punida pelos contratos é que se pode esperar uma reciprocidade negativa, em que as pessoas abdicam dos seus poderes de agirem com as próprias mãos e de devolverem as injustiças que sofrerem. A lei é que deverá se encarregar de punir os injustos.

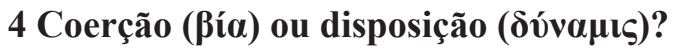

Chegou o momento de explicar a relação entre os argumentos da maioria apresentados por Glaucon e aquilo que o próprio Glaucon e Adimanto esperam de Sócrates. Isso pode ser feito a partir da seguinte pergunta: o que é necessário para o homem ser justo? Se ser justo é simplesmente evitar cometer injustiças, para o homem ser justo é necessário algo que o obrigue e o impeça de ser injusto e isso é obtido pelo contrato. Porém, se ser justo é mais do que evitar cometer injustiças, então precisamos de uma força ou poder interno na própria alma. Aqui emerge um terceiro conceito de força. Além do conceito de justiça como vantagem do mais forte e do conceito de força encontrado no contrato, que

32 Nesse ponto em específico, discordo de Santas (2010, p. 38) e de Allen (1987, p. 5), que defendem esse antes na medida em que parecem afirmar que o contrato emerge como desejo por justiça. O problema é que na "República", "antes" do contrato que evitasse injustiças também existiam contratos e as pessoas também se reuniam para cometer atos injustos justamente com o Estado, as leis e os contratos. A proposta da maioria apresentada por Glaucon é como uma alternativa a esse ambiente no qual os contratos são utilizados para perpetuar as injustiças dos mais fortes, tendo como critério a seguinte igualdade: ninguém cometerá injustiça sem ser punido. Os homens não fazem o contrato para que a justiça seja feita, mas decidem colocar no contrato a punição para quem fizer injustiças. Em outras palavras, não seria exagero dizer, com Lewis, que "aquilo que Platão rejeita é a posição representada no pensamento moderno por Hobbes, a saber, que as ideias de 'direito' e 'dever' não possuem significado fora da esfera da lei” (1939, pp. 79-80). 
nos impede de fazer injustiça, surge também um conceito de poder e de força psíquicas para fazer a justiça, com a tese de Sócrates. No desenvolvimento do livro IV, Sócrates será um grande crítico da tese de que "quanto mais leis melhores e mais justas serão as pessoas", pois, para ele, criar leis para corrigir defeitos ou atitudes más é como cortar a cabeça de Hidra, no lugar da qual sempre vão nascer duas cabeças - ou dois hábitos ruins (426e-427a). Em outras palavras, corrigir leis para corrigir hábitos é como ficar tomando remédio sem alterar o regime de vida (426a). O correto seria encontrar e tentar desenvolver uma disposição voluntária e interna na alma para os atos justos por meio da educação e do modo de vida.

Acima foi dito que a tese apresentada por Glaucon encontra-se dramaticamente no meio das teses de Trasímaco e de Platão. Do ponto de vista conceitual, contudo, a justificativa para o contratualismo não se equilibra entre essas duas teses, pois acaba pendendo mais para as teses de Trasímaco e se distanciando das teses socrático-platônicas. Na tentativa de impor um limite às fraudes dos contratos as pessoas criam mais leis. Porém, como foi visto, o contrato não resolve o problema de uma ação justa voluntária e nem resolve o problema de caráter dos indivíduos que colocam como maior bem serem injustos sem serem punidos. O objetivo de Platão ao elaborar esses argumentos nessa sequência é encontrar a possibilidade de uma ação justa voluntária sem coerção externa.

Platão está procurando um poder da alma que possa ser considerado positivo e isso significa que deveria haver uma certa ação da alma para fazer a justiça na cidade. Esse é o motivo pelo qual Sócrates se distancia das teses da maioria apresentadas por Glaucon para se aproximar das expectativas do próprio Glaucon quando pede junto com Adimanto que Sócrates seja o primeiro a defender a

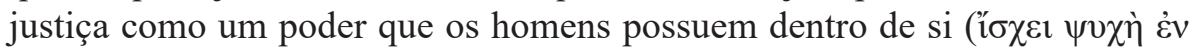

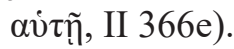

\section{Conclusão}

Portanto, Platão precisa da posição de Glaucon para apresentar a sua própria concepção porque ele pretende encontrar, ao contrário da maioria, qual seria a disposição positiva da alma para fazer um acordo cuja finalidade seja a própria justiça e não somente o medo de sofrer injustiças ou então apenas a justiça interna da alma. A justiça encontrada como divisão de funções não é em um primeiro momento apropriada à cidade, de modo que essa justiça inapropriada será uma imagem onírica para a cidade, sendo aplicável efetivamente somente às ações e às relações internas da alma do homem em relação a si mesmo:

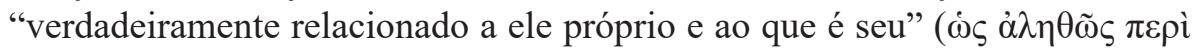




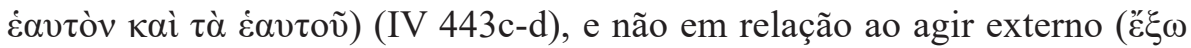
$\pi \rho \tilde{\alpha} \xi ı v)$. Com isso ele encontra na justiça apresentada no livro IV um poder da alma, mas não encontra ainda um poder que possa ser considerado positivo para a cidade ou relativo às ações externas. A ação voluntária justa na cidade só aparecerá efetivamente no horizonte quando fazer justiça se tornar o maior bem para o homem, maior até do que possuir como maior bem a justiça dentro da alma. A posição de Platão a respeito de uma justiça que não esteja apenas relacionada ao cuidado de si só aparecerá com a discussão sobre o bem no livro VI, cujo conhecimento tornará a justiça psíquica útil para a cidade.

Um dos problemas que o próprio Platão apresenta contra a crença nas leis como origem da justiça ocorre sobretudo quando o legislativo é uma das causas do problema da má administração da cidade. Ao contrário disso, no caso de uma cidade bem governada, os homens encontrariam as leis por si mesmos e pelo próprio caráter, sem a necessidade de coerção, que está completamente vinculada à ideia de prisão ( $\dot{\alpha} v \alpha \gamma \kappa \alpha$ Ĩov). É por essa perspectiva que o próprio filósofo na "República" somente se tornará útil para a cidade quando começar a se dedicar à legislação. É nesse momento que o filósofo que odeia as injustiças não se esconde da tormenta das injustiças na sociedade como se estivesse fugindo de uma tempestade ${ }^{33}$ e não fica feliz e satisfeito apenas com a justiça na sua própria alma. Nesse sentido, a discussão sobre a constituição consiste em um dos principais objetivos da vida do filósofo, na medida em que ele busca a constituição adequada para beneficiar os justos e toda a comunidade e não apenas para evitar o temor de sofrer injustiças.

Encontrar a disposição positiva da alma para fazer a justiça para a cidade é o mesmo que encontrar a disposição racional do filósofo para cuidar do governo e da constituição da cidade, e isso só acontece quando o maior bem para cada indivíduo não for aquele que pensa somente na própria preservação. Pode-se até mesmo sustentar como hipótese para trabalhos futuros ${ }^{34}$ que os motivos de Platão apresentar as teses sobre a justiça na sequência escolhida (Trasímaco, Maioria, Sócrates) estariam ligados a um movimento que parte daquilo que pode ser considerado como mais evidente até chegar aquilo que seria mais racional, já que parte da evidência dos fatos históricos, tendo em vista a relação da tese

33 Sobre isso, ver o risco de inutilidade do filósofo no livro e a necessidade de que eles cuidem da constituição da cidade: VI 491d-501e, em especial VI 497a-e.

34 Essa hipótese poderia ser comparada com as qualidades que o filósofo deve ter e como certos tipos psicológicos são vistos como causa das formas de governo, nos livros VIII e IX da "República". Além disso, seria possível também associar essas teses como se cada uma estivesse conectada a uma das três partes da alma apresentada no ícone do livro IX da "República": onde existe no interior do homem um animal multicéfalo, um leão e um hominículo (588b-589a). Os argumentos de Trasímaco poderiam sustentar o animal multicéfalo, os de Glaucon sustentariam a impetuosidade do leão e os de Sócrates a tese do controle racional sobre si mesmo: o homem dentro do homem. 
de Trasímaco com a guerra do Peloponeso, passa pelo sentimento psíquico de temor de sofrer injustiças, presente na explicação da disposição psíquica da multidão apresentada por Glaucon e chega à defesa racional de uma disposição positiva que deveria motivar o filósofo a cuidar da cidade na medida em que se preocupa com aquilo que diz respeito a todos: a constituição (politeía, que é o título em grego da "República").

\section{Referências}

ALLEN, R. E. "The speech of Glaucon in Plato's 'Republic". Journal of the History of Philosophy, Vol. 25, Nr. 1, pp. 3-11, Janeiro 1987.

ANAGNOSTOPOULOS, M. "The Divided Soul and the Desire for Good in Plato's Republic". In: G. Santas (ed.). The blackwell guide to Plato's Republic. Malden, Oxford, Victoria: Blackwell Publishing, 2006. pp. 166-188.

ARAÚJO, C. "Da Arte - Uma leitura do Górgias de Platão". Belo Horizonte: Ed. UFMG, 2008.

ARISTÓTELES. "Ética a Nicômacos”. Tradução de António Caeiro. São Paulo: Atlas, 2009.

BROWN, L. "Glaucon's Challenge, rational egoism and ordinary morality". In: F.-G. Herrmann, T. Penner, D. Cairns (eds.). Pursuing the good: Ethics and Metaphysics in Plato's Republic. Edinburgh: Edinburgh University Press, 2007. pp. 42-60.

CAIRNS, D.; HERRMANN, F.-T.; PENNER, T. "Pursuing the Good. Ethics and Metaphysics in Plato's Republic". Edinburgh: Edinburgh University Press, 2007.

CHANTRAINE, P. (1968) "Dictionnaire étymologique de la langue grecque. Histoire des mots". Tomos I e II. Paris : Les èditions Klincksieck, 1977.

DIXSAUT, M. (org.). "Études sur la République de Platon - 1. De la justice". Paris: Vrin, 2005a.

. "Études sur la République de Platon - 2. De de la science, du bien et des mythes". Paris: Vrin, 2005 b.

FOSTER, M. "A mistake of Plato's in the Republic: a rejoinder to Mr. Mabbott”. Mind, Vol. 47, Nr. 186, pp. 226-232, Abril 1938.

GADAMER, H.-G. “A ideia do Bem entre Platão e Aristóteles". Tradução de Tito Lívio Cruz Romão. São Paulo: Martins Fontes, 2009.

GILBOA, D. “Glaucon's challenge challenged”. Hermathena, Nr. 160, pp. 9-22, Verão 1996.

HITCHCOCK, D. “The Good in Plato's Republic”. Apeiron, 19, 2, pp. 65-92, 1985. KIRWAN, C. "Glaucon's Challenge”. Phrônesis, Vol. 10, Nr. 2, pp. 162-173, 1965.

LEWIS, H. D. "Plato and the Social Contract". Mind, Vol. 48, Nr. 189, pp. 78-81, Jan 1939.

LIDDELL, H., SCOTT, R., JONES, H. (1843). “Greek-English Lexicon”. Oxford, New Ninth Edition, 1996. Disponível em http://www.perseus.tufts.edu/hopper/ resolveform?redirect $=$ true (Acessado em 26 de março de 2016). 
McNEILL D. "Thrasymachus, Rhetoric, and the Art of Rule". In: D. McNeill. An image of the soul in speech: Plato and the problem of Socrates. University Park: Pennsylvania State University Press, 2010. pp. 92-122.

NESCHKE-HENTSCHKE, A. "Justice socratique, justice platonicienne". In: M. Dixsaut (org.). Études sur la République de Platon. Paris: Librairie Philosophique J. Vrin, 2005. pp. 227-246.

NICHOLS, M. "Glaucon's adaptation of the story of Gyges and its implications for Plato's political teaching”. Polity, Vol 17, Nr. 1, pp. 30-39, outono 1984.

PLATÃO. "A República”. Tradução de Ana Lia A. Prado. São Paulo: Martins Fontes, 2006. . "Górgias". Tradução de Daniel Lopes. São Paulo: Perspectiva, 2011.

PLATON. "La République". Traduction inédite, introduction et notes par Georges Leroux. Paris: Flammarion, 2004.

. "Le Politique". Traduction inédite, introduction et notes par Luc Brisson et Pradeau. Paris: Flammarion, 2003.

PLATONIS. "REMPVBLICAM". Recognovit brevique adnotatione critica instrvxit S.R. Sling. Oxford, New York: Oxford University Press, 2003.

RAWLS, J. (2002). "Justiça como equidade - uma reformulação". Tradução de Claudia Berliner. São Paulo: Martins Fontes, 2003.

SANTAS, G. "Justice by Agreement. Is it Good enough? The challenge of Plato's Brother". In: . Understanding the Plato's Republic. Malden, USA; Oxford, UK: Wiley-Blackwell, 2010. pp. 36-54.

. "Methods of Reasoning about Justice in Plato's Republic". In: The blackwell guide to Plato's Republic. 2006a. pp. 125-145.

. "Plato on Pleasure as the Human Good". In: H. Benson (ed.). A companion to Plato. Australia, Oxford, Malden: Blackwell Publishing, 2006b. pp. 308-321.

. "Two theories of good in Plato's Republic". Archiv für Geschichte der Philosophie, 67, 3, pp. 223-245, 1985.

. "The form of the Good in Plato's Republic". In: J. Anton, A. Preus (eds.). Essays in Ancient Greek Philosophy. Albany: State University of New York Press, 1983. pp. 232-63.

SEKIMURA, M. "Platon et la question des images". Bruxelles: Ousia, 2009.

TENENBAUM, S. "Ethical Internalism and Glaucon's Question”. Nô̂s, Vol. 34, Nr. 1, pp. 108-130, março 2000.

TUCÍDIDES. "História da Guerra do Peloponeso". Tradução de Mario Kury. Brasília: Ed. Universidade de Brasília, Instituto de Pesquisas de Relações Internacionais; São Paulo: Imprensa Oficial do Estado de São Paulo, 2001.

VLASTOS, G. "Justice and happiness in the Republic". In: of Critical Essays. Garden City: Doubleday, 1971. pp. 66-95. (éd.). Plato. A Collection

. "Justice and psychic harmony in the Republic". Journal of Philosophy, 66, pp. 505-521, 1969.

. "The theory of social justice in polis in Plato's Republic". In: H. North (org.). Interpretations of Plato. Leiden: E. J. Brill, 1977. pp. 1-40. 